\title{
Beta adrenergic receptors in pigmented ciliary processes
}

\author{
GRAHAM E. TROPE ${ }^{1}$ AND BARRY CLARK ${ }^{2}$ \\ From the 'Tennent Institute of Ophthalmology and the ${ }^{2}$ Department of Pathological Biochemistry, \\ University of Glasgow, Western Infirmary, Glasgow
}

SUMMARY Beta adrenergic receptors from membrane fragments of pigmented sheep eyes were studied and characterised by ligand binding techniques after the removal of melanin. In a representative experiment the $\beta \max$ (total number of beta receptors) was $394.9 \mathrm{fmol} / \mathrm{mg}$ protein. The receptor affinity $(\mathrm{Ka})$ was $440 \mathrm{pM}$. The potency series of drugs to displace ${ }^{125} \mathrm{I}-\mathrm{HY}$ P from the receptors was timolol $=(-)$ propranolol $>(+)$ propranolol $>$ salbutamol $>$ practolol. $\beta_{1}$ Receptors were not detected in the ciliary processes. $\beta_{2}$ Receptors were the prominent adrenergic receptors present. The theory as to how beta blockers work in glaucoma, their site of action, and the potential role of $\beta_{2}$ blockers for use in intraocular pressure control is discussed.

Beta adrenergic blockers are competitive inhibitors of catecholamines binding at $\beta$-adrenergic receptor sites. ${ }^{1}$ Various beta blockers have been shown to reduce intraocular pressure in normal human eyes, glaucomatous patients, ${ }^{2-7}$ and in animal eyes. ${ }^{89}$ It is presumed that these agents exert their intraocular pressure lowering effect by binding to $\beta$-adrenergic receptors in the ciliary processes, ${ }^{10}$ but this is controversial. ${ }^{8}$

A major advance in the study of $\beta$-adrenergic receptors involves the use of radio-ligand techniques. ${ }^{12}$ These allow the identification of the location, number, and subtypes (i.e. $\beta_{1}$ or $\beta_{2}$ ) of adrenergic receptors. ${ }^{13}$ The presence of melanin in the pigmented layer of the ciliary processes has until recently prevented the application of ligand binding techniques to this tissue, because melanin interferes with the assays. We have recently described a method which overcomes this problem..$^{1415}$

The present study demonstrates the presence of $\beta$-receptors in membrane fractions obtained from pigmented ciliary processes and characterises these receptors into their constituent subtypes, namely, $\beta_{1}$ or $\beta_{2}$. The results provide an insight into the mechanism of action of beta blockers currently used in the management of glaucoma.

Correspondence to Graham E. Trope FRCS Ed, Tennent Institute of Ophthalmology, Western Infirmary, Glasgow G11 6NT.

\section{Materials and methods}

Eight freshly enucleated ram eyes were used for each receptor characterisation experiment. A total of 32 eyes were used in this representative series of experiments. The ciliary processes were dissected off the ciliary body and lens under a dissecting microscope and subjected to a ligand binding technique which utilised ${ }^{125}$ iodohydroxybenzyl pindolol $\left({ }^{125} \mathrm{I}-\mathrm{HYP}\right)$ as we have recently described. ${ }^{14}$ Further modifications of our technique include the use of a discontinuous sucrose gradient of 5\%: $50 \%$ with added $0 \cdot 1 \%$ calf serum. The binding affinities of timolol (+) propranolol, (-) propranolol, $( \pm)$ propranolol, salbutamol, and practolol were investigated, and the receptors characterised by a computerassisted nonlinear, derivative-free regression procedure, separating out mixed receptor populations $\left(\beta_{1} / \beta_{2}\right)$ as appropriate.

\section{Results}

Fig. 1 shows a saturation curve which is characteristic of a receptor study. The radioactive material $\left({ }^{125} \mathrm{I}-\right.$ HYP) saturates the beta receptor sites around 500 pM. Specific binding is determined from the equation: total binding-nonspecific binding. ${ }^{14}$ This figure also shows that the results are amenable to Scatchard analysis (insert), an essential prerequisite 


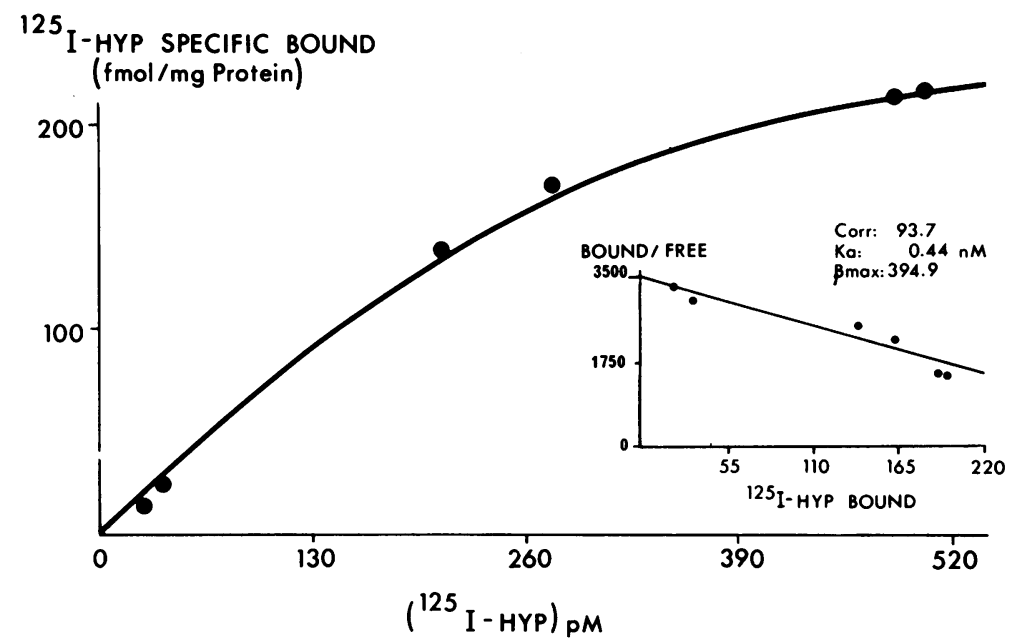

Fig. 1 Saturation binding curve and Scatchard analysis (insert).

for receptor analysis. The total number of receptors $(\beta \max )$ in this representative example is 394.9 $\mathrm{fmol} / \mathrm{mg}$ protein. The receptor affinity $(\mathrm{Ka})$ is $440 \mathrm{pM}$ $(p<0.01)$ and the correlation coefficient $93.7 \%$ for the 6 points.

Fig. 2 further confirms the presence of beta receptors. (-) Propranolol is shown to displace radioactive ${ }^{125} \mathrm{I}-\mathrm{HYP}$ from the receptor sites

125 I-HYP

$\%$ Specific Binding

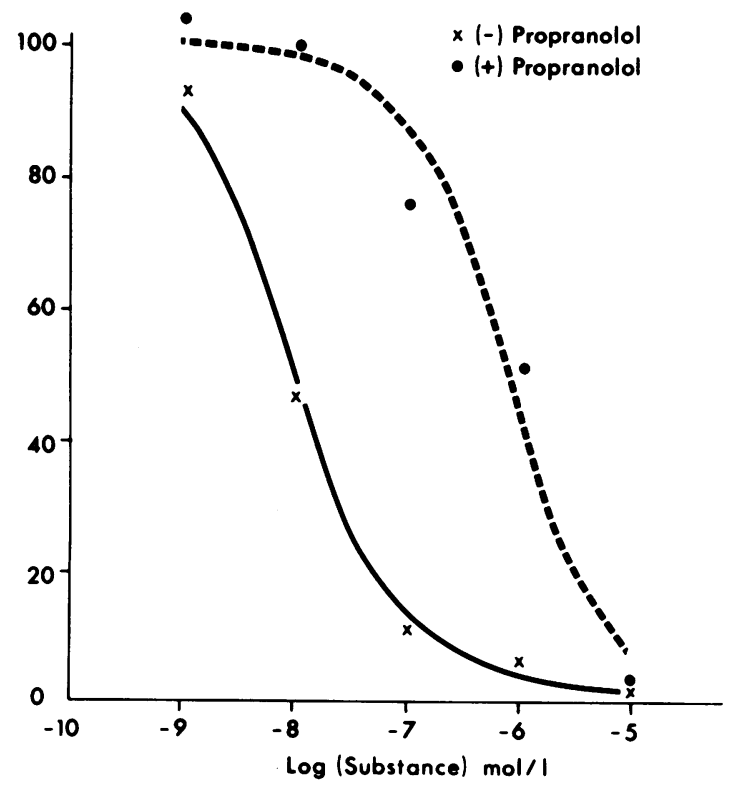

Fig. 2 Relevant potencies of $(-)$ and $(+)$ propranolol in displacing ${ }^{125}$ I-HYP from the receptors. approximately 100 times more potently than $(+)$ propranolol. This effect is typical of a functional receptor.

The computer drawn displacement curve in Fig. 3 compares the effects of salbutamol and practolol to displace ${ }^{125}$ I-HYP from receptor sites. As indicated, salbutamol displaces ${ }^{125}$ I-HYP more potently than practolol off the receptor sites.

125 I-HYP \% SPECIFIC BINDING

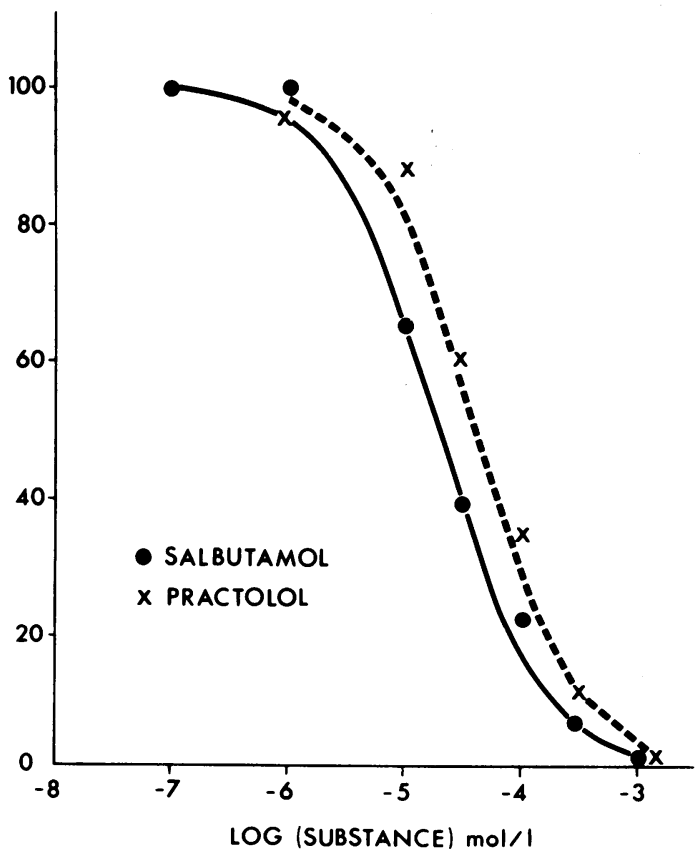

Fig. 3 Displacement curves of salbutamol and practolol. 
125 I-HYP

$\%$ Specific Binding

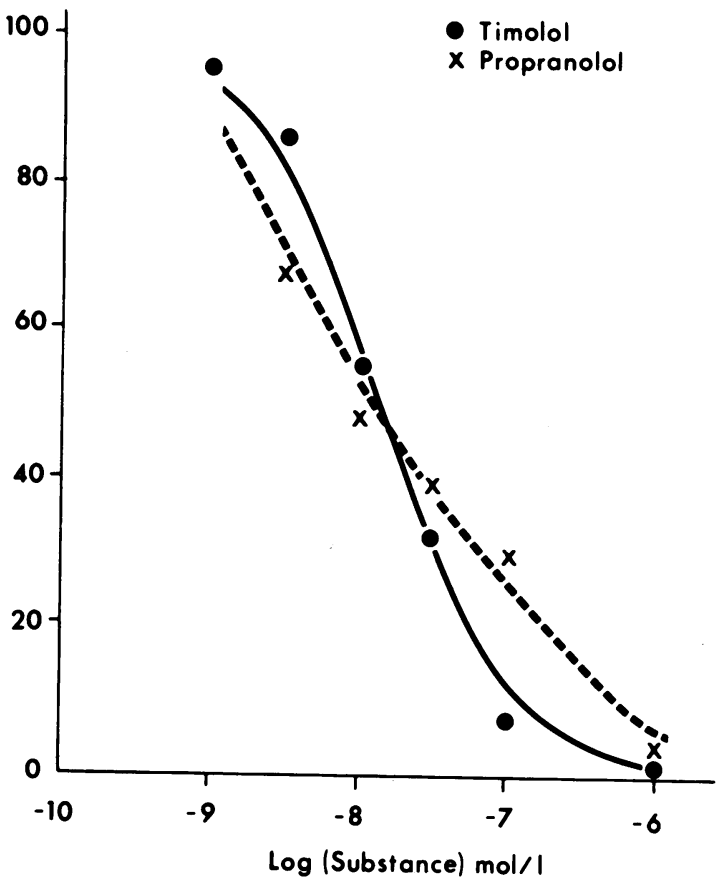

Fig. 4 Displacement curves of timolol and ( \pm ) propranolol.

The computer drawn curve in Fig. 4 compares the ability of timolol and $( \pm)$ propranolol to displace ${ }^{125}$ I-HYP from receptor sites. Timolol displaces ${ }^{125} \mathrm{I}-$ HYP more potently than $( \pm)$ propranolol off the receptor sites.

The receptor characteristics from the above graphs are summarised in Table 1 along with previous results from Trope and Clark, ${ }^{15}$ in which the iris/ciliary body diaphragm was studied. ( \pm ) Propranolol and timolol are nonselective for $\beta_{1}$ and $\beta_{2}$ receptor sites, whereas practolol and salbutamol are selective for $\beta_{1}$ and $\beta_{2}$ receptors respectively. With the revised dissection and density gradient procedures as described above we were unable to detect the presence of $\beta_{1}$ receptors in the ciliary processes. All the beta receptors were of the $\beta_{2}$ subtype.

\section{Discussion}

The discovery that beta blocking agents could lower intraocular pressure ${ }^{16}$ has led to their use for over 10 years in the medical management of primary openangle glaucoma. ${ }^{3}$ How they work is still uncertain. Three possible mechanisms have been suggested. (i) Beta blockers may block beta receptors in the ciliary processes. (ii) They may have an effect on aqueous production through a vasoactive mechanism. ${ }^{81718}$ (iii) They may have some other undetermined effect. ${ }^{8}$

The fact that this study confirms that large numbers of beta receptors exist in the ciliary processes strongly suggests that they influence aqueous production by blocking beta adrenergic receptor sites. This study complements the findings of other workers who, using different techniques, have also detected beta receptors in the ciliary processes. ${ }^{1920}$ It is interesting to note that the dissociation constant $(\mathrm{Kd})$ for timolol obtained by the non-radio-ligand adenyl cyclase method on human ciliary processes ${ }^{19}$ is similar to that in our study of sheep eyes.

The exact role of beta receptor blockade in aqueous formation is not known, but it has been suggested by Thomas and Epstein ${ }^{10}$ and others that beta receptors in the ciliary processes somehow provide 'tonic' activity to the inflow mechanism, and that by blocking these receptors there is a decrease in aqueous production. ${ }^{1021}$ It is possible that this effect is partially mediated by the ion transport mechanism of the epithelial cells of the ciliary processes, which is apparently cyclic-AMP-dependent. ${ }^{822}$

The existence of 2 subtypes of beta adrenergic receptors were first suggested by Land et al. ${ }^{23} \beta_{1}$ Receptors are found mainly in the heart and adipose tissue, and $\beta_{2}$ receptors mainly in the lung and liver.

Table 1 Summary of receptor characteristics

\begin{tabular}{|c|c|c|c|c|}
\hline \multirow[t]{2}{*}{ Drug } & \multicolumn{3}{|c|}{ Dissociation constants (mol/l) } & \multirow{2}{*}{$\begin{array}{l}\text { Receptor subtypes } \\
\text { (\% beta-1: beta }-2)\end{array}$} \\
\hline & Beta-1 & Beta-2 & Non-selective & \\
\hline $\begin{array}{l}\text { (-) Propranolol } \\
\text { (+) Propranolol }\end{array}$ & - & - & $\begin{array}{l}4.6 \times 10-9 \\
3.8 \times 10-7\end{array}$ & - \\
\hline Practolol $^{*}$ & $3.2 \times 10-7$ & $4.9 \times 10-5$ & - & $10 / 90$ \\
\hline Practolol & ND & $2 \cdot 0 \times 10-5$ & - & $0 / 100$ \\
\hline Salbutamol* & $1 \cdot 1 \times 10-4$ & $3 \cdot 0 \times 10-6$ & - & $25 / 75$ \\
\hline Salbutamol & ND & $5 \cdot 1 \times 10-6$ & - & $0 / 100$ \\
\hline Timolol & - & - & $6.4 \times 10-9$ & \\
\hline ( \pm Propranolol) & - & - & $7 \cdot 9 \times 10-9$ & \\
\hline
\end{tabular}

$\mathrm{ND}=$ not detectable. ${ }^{*}$ Iris/ciliary body diaphragm. 
The use of competitive antagonistic drugs in both binding and displacement assays-coupled with computer curve fitting techniques-has enabled more precise detection and characterisation of beta adrenergic receptors and their subtypes where such exist. Similar techniques have recently been used to characterise beta receptors in nonocular sites and to detect beta receptors in albino animal eyes. ${ }^{24-26}$ Attempts to perform these radio-ligand techniques on the pigmented iris ciliary body diaphragm ${ }^{27}$ have been partially obstructed by the presence of melanin in the tissue, as the melanin significantly binds ligand, thereby adversely affecting the results of the assay. ${ }^{14}$ This study uses a new method of separating melanin from ciliary processes. ${ }^{14}$ is Our in-vitro results, as indicated above, not only confirm the presence of beta adrenergic receptors in the ciliary processes of sheep eyes, but indicate that most of these receptors appear to be $\beta_{2}$ in character. This finding supports the clinical evidence that $\beta_{2}$ receptors are probably the major receptors involved in intraocular pressure control. For example, timolol, a nonselective beta blocker, has been shown to have a more potent intraocular lowering pressure effect than metopralol, a $\beta_{1}$ specific blocker. It has been suggested that this effect may be due to the presence of $\beta_{2}$ adrenergic blockers in the ciliary processes. ${ }^{28}$

A potent new $\beta_{2}$ adrenergic blocking drug has recently been described. ${ }^{29}$ This agent, called IPS 339 , is said to be more specific than any other $\beta_{2}$ adrenergic blocking drug available at present.$^{19}$ It has been reported to lower the intraocular pressure in normal rabbits. ${ }^{30}$ Initial ligand binding studies with this drug on pigmented ciliary processes indicate that it binds potently to $\beta_{2}$ receptors in our membrane preparations.

By using only the ciliary processes (i.e., no iris or ciliary body) and by modifying our density gradient we have effectively removed most $\beta_{1}$ receptors from our membrane preparations (Table 1). Our previous study on the iris ciliary body diaphragm indicated a mixed receptor population of $\beta_{1}$ to $\beta_{2}$ receptors of 10-25\%: $75-90 \% .{ }^{15}$ It seems likely that most of the $\beta_{1}$ receptors removed with our modified technique were situated in muscle fibres and/or large vessels of the iris ciliary body diaphragm.

If beta blockers like timolol exert their effect through blockage of beta adrenergic receptors, it is acceptable to speculate that there will be an accumulation of transmitter agent in the synaptic cleft. It is conceivable that this excess noradrenaline may diffuse into the stroma of the ciliary process and by means of alpha receptors constrict the blood vessels supplying the ciliary processes. Most blood vessels are known to contain alpha receptors which cause vasoconstriction. ${ }^{13}$ This vasoconstriction could then lead to a decrease in the intraocular pressure as the blood supply to the ciliary processes decreases. As a result, beta blockers may have both a beta blocker and a vascular effect which together lower intraocular pressure. Further studies on both alpha and beta receptors, particularly in human eyes, may prove of value in determining the mechanism of action of drugs currently available to treat open-angle glaucoma.

This work is supported by the Frost Charity Foundation. We thank Professor W. Foulds, Dr R. Logan. Professor W. Lee, Dr J. Jay, and Dr J. Forrester for their help and support in preparing this paper. We thank the following drug companies for donating drugs to us: ICl (practolol and propranolol); Merck Sharp and Dohme (Timolol); and Allen and Hanbury (salbutalol). We thank Dr G. Leclerc for supplying us with IPS 339 .

\section{References}

1 Koch-Weser J, Frischman WH. Beta adrenoreceptor antagonists: new drugs and new indications. $N$ Engl J Med 1981; 305: $500-6$.

2 Zimmerman TJ. Boger WP. Beta adrenergic blocking agents and the treatment of glaucoma. Surv Ophthalmol 1979; 23: 347-362.

3 Krieglstein GK. The longterm ocular and systemic effects of topically applied metoprolol tartrate in glaucoma and ocular hypertension. Acta Ophthalmol (Kbh) 1981; 59: 15-20.

4 Bonomi L, Steindler P. Effects of pindolol on intraocular pressure. Br J Ophthalmol 1975; 59: 301-3.

5 Krieglstein GK. Kontic D. Nadalol and lobetalol: comparative efficacy of two beta blocking agents in glaucoma. Albrecht von Graefes Arch Klin Ophthalmol 1981; 216: 313.

6 Eliott J, Cullen PM, Phillips CI. Ocular hypotensive effects of atenolol (Tenormin) - a new beta adrenergic blocker. Br J Ophthalmol 1975; 59: 296-300.

7 Smith SE, Smith SA. Reynolds F, Whitmarsh VB. Ocular and cardiovascular effects of local and systemic pindolol. $B r J$ Ophthalmol 1979; 63: 63-6.

8 Neufield AH. Experimental studies of the mechanisms of action of timolol. Surv Ophthalmol 1979; 23: 363-70.

9 Vareilles P. Silverstone D, Plazonett B, et al. Comparison of the effects of timolol and other adrenergic agents on intraocular pressure in the rabbit. Invest Ophthalmol Visual Sci 1977; 16: 987-96.

10 Thomas JV, Epstein DL. Study of the additive effects of timolol and epineprine in lowering intraocular pressure. BrJ Ophthalmol 1981: 65: 596-602.

12 Hoffman D, Lefkowitz RJ. Radio ligand binding studies of adrenergic receptors: new insights into molecular and physiological regulation. Annu Rev Toxicol Pharmacol 1980; 20: $581-608$.

13 Lees G. A hitch-hiker's guide to the galaxy of adrenoreceptors. Br Med J 1981; 283: 173-8.

14 Trope GE, Clark B, Titinchi SJS. Identification of beta adrenergic receptors in the pigmented mammalian iris-ciliary body diaphragm. Exp Eye Res 1982; 34: 153-7.

15 Trope GE, Clark B. Characteristics of beta receptors and the affinity of timolol to bind to these receptors in the pigmented iris ciliary body diaphragm. Ophthalmic Res in press.

16 Phillips CI, Howitt G, Rowlands DJ. Propranolol as ocular hypotensive agent. Br J Ophthalmol 1967; 51: 222-6.

17 Christini G, Giovannini A. Pressure lowering effect of timolol with reference to its topical vascular action. Albrecht von Graefes Arch Klin Ophthalmol 1979; 211: 325-8. 
18 Langham ME. Craigie B. The specificity and vascular mechanism of timolol. ARVO Abstr 1979; 330: 164 .

19 Nathanson JA. Human ciliary process adrenergic receptors: pharmacological characterisation. Invest Ophthalmol Visual Sci 1981; 20: 798-804.

20 Dafna Z, Lahav M, Melamed E. Localisation of betaadreno receptors in the anterior segment of the albino rabbit eye using a fluorescent analog of propranalol. Exp Eye Res 1979; 29: 327-30

21 Coakes RL. The role of fluorophotometry in glaucoma research. Res Clin Forums 1980; 2: 101-4.

22 Cole DF, Nagasubramian S. The effect of natural and synthetic vasopressins and other substances on active transport on the ciliary epithelium of the rabbit. Exp Eve Res 1972; 13: 45-57.

23 Lands AN, Arnold A, McAuliff JP, Luduena FP, Brown JG. Differentiation of receptor systems activated by sympathomimetic amines. Nature $1967 ; 214: 597-8$.

24 Neufield AH, Page ED. In vitro determination of the ability of drugs to bind to adrenergic receptors. Invest Ophthalmol Visual Sci 1977; 16: 1118-24.

25 Bromberg BB, Gregory DS, Sears ML. Beta adrenergic receptors in ciliary processes of the rabbit. Invest Ophthalmol Visual Sci 1980; 19: 203-7.

26 Minneman KP. Hedberg A. Molinoff PB. Comparison of beta adrenergic receptors subtypes in mammalian tissue. J Pharmacol Exp Ther 1979; 211: 502-8.

27 Bahargava G, Makman MH, Katzman R. Distribution of beta adrenergic receptors and isoproterenol stimulated cyclic amp formation in monkey iris and ciliary body. Exp Eye Res 1980; 37: 471-7.

$28 \mathrm{Alm} \mathrm{A}$, Wickstrom CP, Tornquist P. Initial and long term effects of metopralol and timolol on the intraocular pressure-a comparison in healthy subjects. Acta Ophthalmol (Kbh) 1982; 59: $510-6$.

29 Imbs JL, Miesch F. Schwartz J, Velley J, Le Clare G, Mann A. Wernuth $\mathrm{G}$. A potent new $\boldsymbol{\beta}_{2}$ adreno receptor blocking agent. $\mathrm{Br}$ J Pharmacol 1977; 60: 347-62.

30 Nathanson JA. Effects of a potent new adrenoreceptor antagonist on intraocular pressure. Br J Pharmacol 1981; 73: 97-100. 